Asian J. Med. Biol. Res. 2015, 1 (2), 198-208; doi: 10.3329/ajmbr.v1i2.25612

\author{
Asian Journal of \\ Medical and Biological Research \\ ISSN 2411-4472 (Print) 2412-5571 (Online) \\ www.ebupress.com/journal/ajmbr
}

\title{
Article
}

\section{Ecology and water quality parameters of Balla beel in Moulovibazar district of Bangladesh}

\author{
Flura $^{1}$, Mohammad Ashraful Alam ${ }^{1}$, Md. Anisur Rahman ${ }^{1}$, Tayfa Ahmed ${ }^{1}$ and Krishna Chandra Roy ${ }^{2}$ \\ ${ }^{1}$ Bangladesh Fisheries Research Institute, Riverine Station, Chandpur, Bangladesh \\ ${ }^{2}$ Department of Fisheries Management, Hajee Mohammad Danesh Science and Technology University, \\ Dinajpur, Bangladesh
}

*Correspondence author: Flura, Bangladesh Fisheries Research Institute, Riverine Station, Chandpur, Bangladesh. Email: flura_bfri@yahoo.com

Received: 16 July 2015/Accepted: 11 August 2015/ Published: 30 September 2015

\begin{abstract}
A study was carried out to assess the ecological aspects of Balla beel ecosystem in Moulavibazar district and the affectivity of the ongoing biodiversity restoration program from July 2011 to June 2012. Seventy-four fish species belonging to 21 families were identified during the study period. About nine types of fishing methods and one type of fish aggregating device were identified in the surveyed beel. Increasing pressure of illegal current jal (gill net), ber jal (seine net) and FAD (Fish Aggregating Device) was detected as the reduction of almost all type of species. About 24 aquatic weeds were found in the Balla beel, among them both emergent and spreading were $29 \%$, followed by floating $21 \%, 13 \%$ were rooted plants with floating leaves and $8 \%$ were submerged. The dissolved oxygen content $5.22 \pm 1.60 \mathrm{mg} / \mathrm{l}$ inside and $5.70 \pm 1.38 \mathrm{mg} / \mathrm{l}$ outside of the Balla beel sanctuary were found to be congenial for aquatic life. $\mathrm{pH}$ of the beel water both inside and outside of the sanctuary were slightly acidic to moderately alkaline $(7.0 \pm 0.68$ inside and $6.88 \pm 0.43$ outside the sanctuary). Lower values of alkalinity and hardness indicating beel water to be less nutrient enriched. The contribution of phytoplankton (79\%) was larger than zooplankton (21\%). The diversity of phytoplankton both inside and outside of the sanctuary was dominated by three group Chlorophyceae, Myxophyceae and Bacillariophyceae.
\end{abstract}

Keywords: ecology; water quality parameter; Balla beel

\section{Introduction}

Bangladesh is blessed with enormous open water fisheries resources with an area of 4.90 million hectors. The inland open water fisheries resources of Bangladesh are the third richest in the world after China and India. These vast Inland open water fisheries resources composed of river and estuaries, beels (natural depression) and baors (Dead River) flood lands (seasonal floodplain) and a man-made Kaptai lake. A large number of fish species and aquatic flora inhabit in its extensive inland open water bodies. Over the last four decades the production from inland open water have been facing gradual declension due to many natural calamity and anthropogenic reasons like use of chemicals in agricultural fields; unplanned construction of roads, embankments and dams; over fishing; use of harmful fishing gears and systems; siltation of water bodies etc. Decrease in fish catch increasingly threatens the livelihoods of more than 12 million fishers in Bangladesh (Tsai and Ali, 1997). According to a study, 42 fish species are endangered and 12 are critically endangered (IUCN, 2000). To mitigate the prevailing situation it is necessary to design effective interventions, policies, and management options. 
Hail Haor is a large wetland in Sreemongol Upazilla under Moulavibazar District, in northeastern of Bangladesh. This haor covers an area of 1400 hectares in the wet season, but in the dry season, it shrinks to become about 130 beels and narrow canals covering a total area of less than 400 hectares. More than 172,000 peoples in 30,000 households were involved in fishing in the haor, many as regular professionals (Chakraborty et al., 2005).

A total area of beels in Bangladesh has estimated to be 114,161 ha, occupying $27.0 \%$ of the inland freshwater area. Bernacsek et al. (1992) has reported that the number of beels in the Northeast region between 3,440 (covering 58,500 ha with a mean size of 7ha) and 6,149 (covering 63,500 ha with a mean size of 10ha). About $58 \%$ of the beels in the northeast region are permanent and the rest is seasonal. Balla beel is a part of the Hail Haor. It currently supports about 90 species of fish and is important as a bird sanctuary. Every year in winter season, hundreds of bird species come here and tourists from home and abroad visit this place for its natural beauty and biological diversity (Mahbub, 2012). Balla beel sanctuary has designed to conserve and restore fish. The Bangladesh Government declared Balla beel as a permanent sanctuary on July 1, 2003 and set about 100 hectares aside. This site was managed through a project called Management of Aquatic Ecosystem through Community Husbandry (MACH). After the end of MACH project in 2008, the sanctuary continued to operate a wide range of protected areas in Bangladesh, including the hail haor wetland of which Balla beel is a part. Objective of the declaration of Balla beel as a sanctuary was to improve wetland habitat for existing flora and fauna and to protect wetland biodiversity.

\section{Materials and Methods}

\subsection{Study site and duration}

The study was conducted in the Balla beel under Moulavibazar District from July 2011 to June 2012 (Figure 1). Balla beel was about 70.74 ha of wetlands in the eastern part of Hail haor near Sreemongal, a tea-growing town in Moulavibazar district. Balla beel includes three sub-beels Chapra, Maguara and Jaduria with surrounding marshy areas known as Balla beel sanctuary.

\subsection{Data collection}

Detail survey on flora and fauna of the Balla beel was conducted with particular emphasis on water quality, biological productivity and biotic communities and status of fishery exploitation. Operationalized research was carried out through collection of both primary and secondary data, comprehensive literature review and extracts of local knowledge and information. Field observation and different experimentation viz. experimental fishing within the beel ecosystem outside the sanctuary, survey of fish market adjacent to beel, survey of katha and kua fishing, monitoring of water quality, recording of water level and fisher's perception were made for primary data. Secondary data were collected from Beel Management Committee (BMC), Local administrations, Water Development Board (WDB), Department of Fisheries, Meteorological Department and related NGOs.

\subsection{Measurements of water quality parameters}

Hydrological, meteorological, physico-chemical and biological characteristics of beel ecosystem have been monitored monthly basis. In each sampling day, water quality data was collected from both inside and outside of the beel sanctuary separately. A bamboo made meter scale measured water depth. A seechi-disc measured transparency. A centigrade thermometer measured temperature of air and water. Free $\mathrm{CO}_{2}$ content was determined by phenolphthalein indicator method (Welch, 1948). Total alkalinity was estimated by using phenolphthalein and methyl orange indicator method (Welch, 1948). Total hardness was determined by EDTA titrimetric method (APHA, 1995). HACH test kit (Model-FF-2, USA) was used to measure $\mathrm{pH}$, dissolved oxygen (DO), ammonia and nitric acid only. For plankotonic study, water (50L) was collected from euphotic zone of the beel and passed through bolting silk plankton net of $55 \mu$. The filtrates were preserved in Luglo's solution.

\subsection{Sampling for fish species}

An organized sampling program was run for a long time to get a true picture of the catch and catch composition of surveyed beel. The experimental beel were sampled during winter (mid November to mid February), pre monsoon (mid February to April), monsoon (May to August) and post monsoon (September to mid November) for assessment of aquatic lives' abundance and availability. Identification of resident as well as migratory fishes was done through collection of different species directly from fisher's catch, experimental fishing, fishing 
through enclosure bana (made by bamboo), Kua fishing and surveying local fish markets. Resident fish species were recorded through experimental fishing in the deep pool areas in the beel and manmade kuas where water remains during dry season (early January- mid April). Local knowledge as well as fisher's perception has been considered for conceptual knowledge regarding the identification of resident fishes.

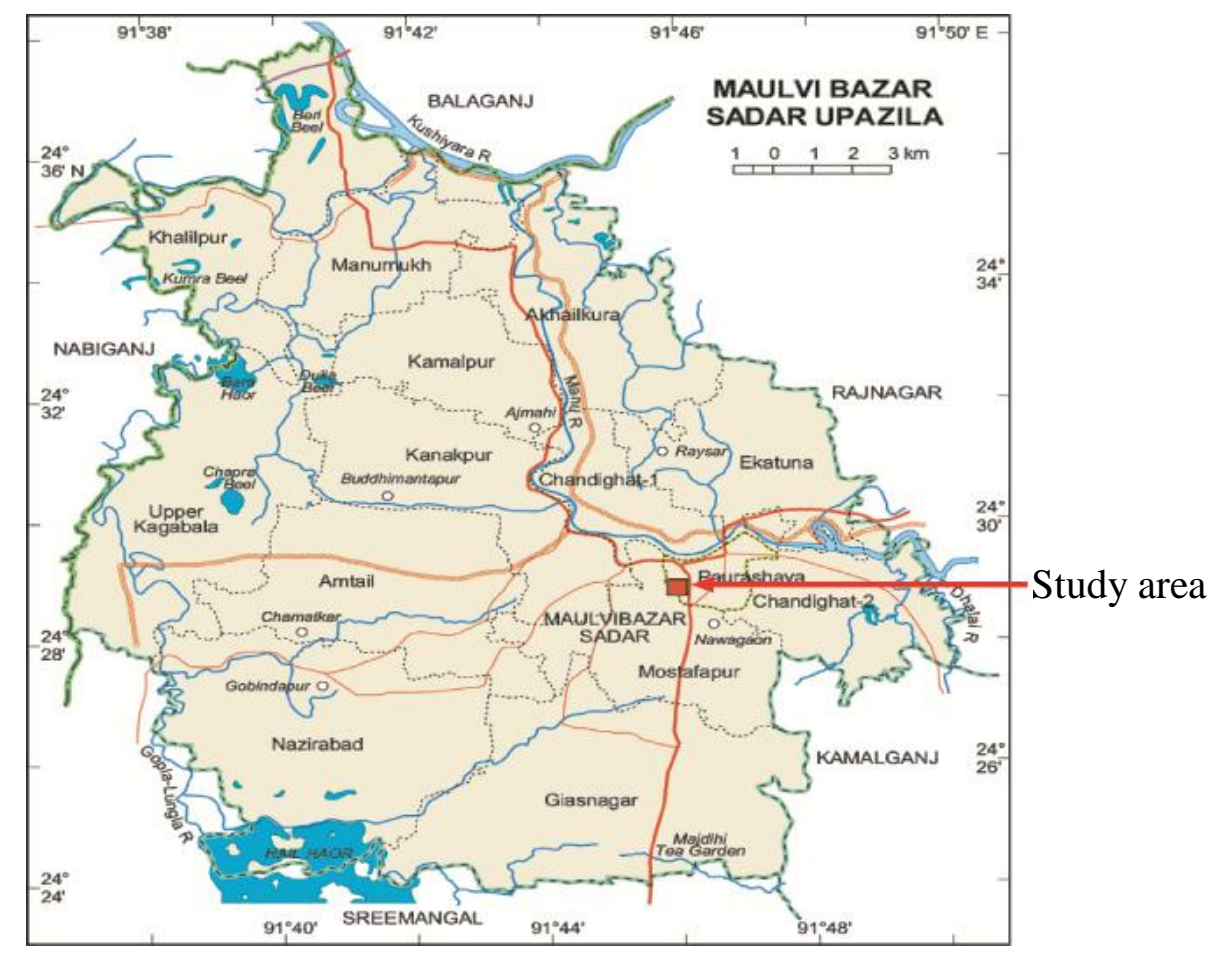

Figure 1. Map of the study area.

\subsection{Fishing method}

Detail survey on fishing method of the Balla beel was conducted with particular emphasis on number of different gears. Fishermen used boat for transport of nets and related materials and used ber jal (seine net), thela jal (push net), lift net, cast net, current jal (gill net), hook and lines etc. according to season and availability of different species of fish. During monsoon and post monsoon, fisher's used lift net, current jal, cast net, hook and lines (barsi, jhupi, aikra, etc.) to catch fishes. They also operated katha fishing by sein net in winter and spring season.

\subsection{Study of plankton and aquatic weeds}

The plankton sample was collected fortnightly from the euphotic zone using 0.55 blotting silk plankton net and later analyzed numerically with the help of Sedgewick-Rafter counting cell (SR-cell) under a compound microscope according to Clesceri et al. (1989). Qualitative and quantitative analysis of both phytoplankton and zooplankton were done following drop count method (APHA, 1995). Microscopic identification was performed up to genera. Each sample was tired smoothly just before microscopic analysis. One ml of agitated sample was poured in a Sedgwick-Rafter $(S-R)$ cell counter. A binocular microscope was used $(10 \times 0.25$ magnification) for identification and enumeration of samples. Qualitative studies were done according to Prescott (1962) and Needham (1962). Different types of aquatic weeds (floating, spreading, emergent, rooted plants with floating leaves) were collected from the beels and identification was made in the laboratory.

\section{Results and Discussion}

\subsection{Water quality parameters}

The physico-chemical factors and plankton were found more or less in normal range in the surveyed beel (Table 1), which was agreed by APHA (1995). Transparency was consistently higher in deeper portion of the beel, possibly due to stagnancy of water. Rahman (1992) stated that the transparency of productive water bodies should be $40 \mathrm{~cm}$ or less. The uniformly average value of oxygen range in inside $5.14 \pm 1.45 \mathrm{mg} / \mathrm{l}$ and outside $5.70 \pm 1.56 \mathrm{mg} / \mathrm{l}$ as noted in the beel agreed well with the findings of APHA (1998). $\mathrm{pH}$ value in inside 
$7.01 \pm 0.71$ and outside $6.89 \pm 0.34$ of the beel was more or less similar with the findings of Rahman (2003), Kohinoor et al. (1994) and Chakraborty et al. (2003). Alkalinity levels indicate medium to higher level of productivity. An alkalinity level of the beel was medium to high that also agreed with the findings of Clesceri et al. (1989). The temperature of the survey area was within the acceptable range that agreed well with the findings of Haque et al. (1993). Transparency was more or less similar in the beel due to the availability of the plankton population Haque et al. (1993). The dissolve oxygen was in acceptable range compared to ponds stocked with a same density. Boyd (1982) observed similar results. Fluctuation of dissolve oxygen concentration may be attributing to photosynthetic activity and variation in the rate of oxygen consumption by fish and other aquatic organisms (Boyd, 1982).

\subsection{Fish species diversity}

The fish species diversity of the beel was virtually enriched along with the presence of large number of indigenous species. During June 2012, 74 fish species were found in the Balla beel. Among 74 fish species, maximum 32 species belonged to the family Cyprinidae followed by Bagridae ( 6 species), Chanidae (4 species) and Siluridae (4 species). Rest of the species belonged to another 17 families (Table 2). The status of the 74 fish species of Balla beel was ranked as different status. Important 12 fish species such as Amblypharyngodon mola, Chela laubuca, Puntius chola, Puntius conchonius, Puntius puntio, Puntius ticto, Rasbora daniconius, Salmostoma phulo, Chanda nama, Chanda beculis, Chanda ranga and Colisa fasciata were found very common (+++) in the sanctuary area of the Balla beel. On the other hand 25 fish species such as Xenentodon cancila, Corica soborna, Botia Dario, Esomus danricus, Labeo gonius, Puntius gelius, Puntius sarana, Puntius sophore, Notopterus notopterus, Anabas testudineus, Badis badis , Channa orientalis, Channa punctata, Channa striata, Colisa lalia, Glossogobius giuris, Clarius batrachus, Clupisoma garua, Heteropneustes fossilis, Mystus bleekeri, Mystus tengara, Mystus vittatus, Macrognathus aculeatus, Macrognathus pancalus and Tetraodon cutcutia were found in common (++) phenomena in the sanctuary and rest 37 fish species such as Anguilla bengalensis, Monopterus cuchia, Gudusia chapra, Barbonymus goninotus, Catla catla, Cirrhinus cirrhosus, Crossocheilus latius, Ctenopharyngodon idella, Cyprinus carpio var. communis, Cyprinus carpio var. specularis, Hypophthalmichthys molitrix, Aristichthys nobilis, Labeo bata, Labeo boga, Labeo calbasu, Labeo nandina, Labeo rohita, Puntius gonionotus, Raiamas bola, Crossocheilus latius, Osteobrama cotio, Chitala chitala, Anabas cobojius, Channa marulius, Ailia coila, Bagarius bagarius, Batasio batasio, Eutropiichthys vacha, Gagata gagata, Ompok bimaculatus, Ompok pabda, Sperata aor, Sperata seenghala, Wallago attu, Mastacembelus armatus, Monopterus cuchia and Ophisternon bengalense were found in rare (+) condition in the sanctuary area of the Balla beel. It was also observed that, 11, 16 and 47 fish species were found in very common $(+++)$, common $(++)$ and rare $(+)$ in the Balla beel outside the sanctuary area (Table 2). According to IUCN (1998), in Bangladesh about 56 freshwater fish species is critically endangered some are still found in Balla beel to a little extent viz. Chital, Rita, Baga air, Chepchela, Tatkini, Kaliboush, Gonia, Sharpunti, Rani, Modupabda, Napit Koi, Gozar etc. The total catch statistics of aquatic lives in the surveyed beel indicated that percentage of different groups of aquatic live was sharply decrease within the year, which was very similar to the study of Chakraborty (2009 and 2010). Due to over-exploitation and various ecological changes in natural aquatic ecosystem, commercially important aquatic lives were in the verge of extinction, which was in agreement with the findings of Sarker (1993). Intervention to control floods, adoption of new agricultural technologies and construction of road networks was altered the ecology of beel significantly which supported the views of Khan (1993) and Ali (1991). Stock of the wildlife brood fishes in their breeding ground was also suffered significant damages resulting in a reduction of biodiversity as noted by Nishat (1993) and Chakraborty (2010).

\subsection{Fishing gears}

In Balla beel, various types of fishing gears were found to operate for fish catching. Traditional fishing gears, different nets, wounding gears, fish aggregating devices (kua/katha) were also found in this beel. It was revealed that, maximum time required for catching fish by current jal and long line where minimum in thela jal. The largest CPUE was found in katha and lowest in thela jal respectively (Table 3). The fishing effort with various types of fishing methods such as seine net (especially ber jal), gill net (current jal) and FAD (kua/katha) was increased during the study period. As a result, an average number of fishes and other aquatic lives declined in the surveyed beel. Cast net (Jhaki jal) was used whole year in the beel. It is a very popular fishing method and used in all over the Bangladesh (Ahmad, 1962). Suganan and Bhattacharjya (2000) found a wide variety of 
fishing methods (passive gear, active gear, FAD, falling gear, dewatering) employed in the beels of Assam, which are very similar to the present findings. The study clearly indicated that the aquatic lives of the beel were subjected to over fishing resulting in gradual decline in aquatic population. Indiscriminate killing of fish occurred due to the use of pesticides in improper doses, use of forbidden chemicals, and aerial spray of chemicals as used in paddy field which was very much similar to the observation of Mazid (2002) and Chakraborty (2010). Haroon et al. (2002) reported eighteen types of fishing gears recorded from the Sylhet subbasin and thirteen types from Mymensingh sub-basin. They also recorded many kinds and sizes of bamboo made traps.

\subsection{Planktonic biomass}

Abundance of plankton in sanctuary and non-sanctuary areas showed a wide range of variation. Average total plankton density (Nos./l) outside the sanctuary areas of Balla beel was higher $(28,552 \pm 7,486)$ than the sanctuary areas $(25,117 \pm 8,114)$ (Table 4). Among the planktonic algae, 45 genera of phytoplankton under 6 families which was more or less similar to the observation of Sugunan and Bhattacharjea (2000) and 12 genera of zooplankton under 9 families were recorded inside the sanctuary areas of Balla beel, which were closer to the study of Ahmed et al. (1997) and Sugunan and Bhattacharjea (2000). In the study area, the phytoplankton abundances were consistently higher than that of zooplankton. Similar results also recorded in various food habits of fish, fry and fingerling rearing in ponds (Chakraborty et al., 2003). Higher phytoplankton concentrations in water normally indicate higher productivity. The higher abundance of phytoplankton compared to zooplankton might be due to regular fertilization and excess uneaten feed that is agreed by Sugunan, Bhattacharjea, (2000) and Keshavanath et al., 2002.

In case of outside the sanctuary Balla beel, about 36 genera of phytoplankton under 6 families and 12 genera of zooplankton under 10 families were found (Table 5). The presence of higher content of fish biomass inside the sanctuary might exert a significant role on the presence of lower amount of planktonic algae over there, because higher the amount of fish higher the predation over the planktonic mass.

Table 1. Physico-chemical parameters of Balla beel (inside and outside the sanctuary).

\begin{tabular}{|l|l|l|}
\hline Parameters & Inside & Outside \\
\hline Water depth $(\mathrm{m})$ & $2.10 \pm 0.92$ & $1.99 \pm 0.81$ \\
\hline Air temperature $\left({ }^{0} \mathrm{C}\right)$ & $30.95 \pm 3.48$ & $30.30 \pm 3.91$ \\
\hline Water temperature $\left({ }^{0} \mathrm{C}\right)$ & $29.57 \pm 4.16$ & $28.14 \pm 4.91$ \\
\hline Water colour & Brownish & Brown \\
\hline Bottom Type & Soft and muddy & Hard and muddy \\
\hline Transparency $(\mathrm{m})$ & $66.77 \pm 39.61$ & $90.50 \pm 28.55$ \\
\hline Dissolve $\mathrm{O}_{2}(\mathrm{mg} / \mathrm{l})$ & $5.14 \pm 1.45$ & $5.70 \pm 1.56$ \\
\hline Free $\mathrm{CO}_{2}(\mathrm{mg} / \mathrm{l})$ & $6.86 \pm 2.23$ & $6.72 \pm 2.10$ \\
\hline pH & $7.01 \pm 0.71$ & $6.89 \pm 0.34$ \\
\hline $\mathrm{NH}(\mathrm{mg} / \mathrm{l})$ & $0.10 \pm 0.23$ & $0.11 \pm 0.00$ \\
\hline Total alkalinity $(\mathrm{mg} / \mathrm{l})$ & $33.71 \pm 19.38$ & $33.94 \pm 10.67$ \\
\hline Total hardness $(\mathrm{mg} / \mathrm{l})$ & $33.79 \pm 15.93$ & $35.84 \pm 9.87$ \\
\hline
\end{tabular}

Table 2. Fish species diversity of Balla beel.

\begin{tabular}{|l|l|l|l|l|l|l|}
\hline Sl. No. & Order & Family & Local name & Scientific Name & Sanctuary & $\begin{array}{l}\text { Non- } \\
\text { sanctuary }\end{array}$ \\
\hline 1. & Anguilliformes & Anguillidae & Banehara & Anguilla bengalensis & + & + \\
\hline 2. & Anguilliformes & Anguillidae & Kuchia & Monopterus cuchia & + & + \\
\hline 3. & Beloniformes & Belonidae & Kakila & Xenentodon cancila & ++ & + \\
\hline 4 & Clupeiformes & Clupeidae & Kachki & Corica soborna & ++ & +++ \\
\hline 5. & Clupeiformes & Clupeidae & Chapila & Gudusia chapra & + & + \\
\hline 6. & Cypriniformes & Cyprinidae & Mola & Amblypharyngodon mola & +++ & ++ \\
\hline 7. & Cypriniformes & Cyprinidae & Rajputi & Barbonymus goninotus & + & + \\
\hline 8. & Cypriniformes & Cobitidae & Bou mach & Botia dario & ++ & + \\
\hline 9. & Cypriniformes & Cyprinidae & Katol & Catla catla & + & + \\
\hline 10. & Cypriniformes & Cyprinidae & Chep chela & Chela laubuca & +++ & ++ \\
\hline
\end{tabular}




\begin{tabular}{|c|c|c|c|c|c|c|}
\hline Sl. No. & Order & Family & Local name & Scientific Name & Sanctuary & $\begin{array}{l}\text { Non- } \\
\text { sanctuary }\end{array}$ \\
\hline 11. & Cypriniformes & Cyprinidae & Mrigal & Cirrhinus cirrhosus & + & + \\
\hline 12. & Cypriniformes & Cyprinidae & Minor carp & Crossocheilus latius & + & + \\
\hline 13. & Cypriniformes & Cyprinidae & Grass carp & $\begin{array}{l}\text { Ctenopharyngodon } \\
\text { idella }\end{array}$ & + & + \\
\hline 14. & Cypriniformes & Cyprinidae & Common carp & $\begin{array}{l}\text { Cyprinus carpio var. } \\
\text { communis }\end{array}$ & + & + \\
\hline 15. & Cypriniformes & Cyprinidae & Mirror carp & $\begin{array}{l}\text { Cyprinus carpio var. } \\
\text { specularis }\end{array}$ & + & + \\
\hline 16. & Cypriniformes & Cyprinidae & Darkina & Esomus danricus & ++ & +++ \\
\hline 17. & Cypriniformes & Cyprinidae & Silver carp & $\begin{array}{l}\text { Hypophthalmichthys } \\
\text { molitrix }\end{array}$ & + & + \\
\hline 18. & Cypriniformes & Cyprinidae & Big head carp & Aristichthys nobilis & + & + \\
\hline 19. & Cypriniformes & Cyprinidae & Bata & Labeo bata & + & + \\
\hline 20. & Cypriniformes & Cyprinidae & Bhangan & Labeo boga & + & + \\
\hline 21. & Cypriniformes & Cyprinidae & Kalibaus & Labeo calbasu & + & + \\
\hline 22. & Cypriniformes & Cyprinidae & Shada ghonia & Labeo gonius & ++ & ++ \\
\hline 23. & Cypriniformes & Cyprinidae & Nandil & Labeo nandina & + & - \\
\hline 24. & Cypriniformes & Cyprinidae & Rui & Labeo rohita & + & + \\
\hline 25. & Cypriniformes & Cyprinidae & Rajpunti & Puntius gonionotus & + & + \\
\hline 26. & Cypriniformes & Cyprinidae & Punti & Puntius chola & +++ & +++ \\
\hline 27. & Cypriniformes & Cyprinidae & Kanchan punti & Puntius conchonius & +++ & +++ \\
\hline 28. & Cypriniformes & Cyprinidae & Gilipunti & Puntius gelius & ++ & ++ \\
\hline 29. & Cypriniformes & Cyprinidae & Punti & Puntius puntio & +++ & +++ \\
\hline 30. & Cypriniformes & Cyprinidae & Shorpunti & Puntius sarana & ++ & + \\
\hline 31. & Cypriniformes & Cyprinidae & Bhadi punti & Puntius sophore & ++ & + \\
\hline 32. & Cypriniformes & Cyprinidae & Tit punti & Puntius ticto & +++ & +++ \\
\hline 33. & Cypriniformes & Cyprinidae & Bhol & Raiamas bola & + & + \\
\hline 34. & Cypriniformes & Cyprinidae & Darkina & Rasbora daniconius & +++ & +++ \\
\hline 35. & Cypriniformes & Cyprinidae & Chela & Salmostoma phulo & +++ & +++ \\
\hline 36. & Cypriniformes & Cyprinidae & Tatkini/Kalabata & Crossocheilus latius & + & + \\
\hline 37. & Cypriniformes & Cyprinidae & Dhela & Osteobrama cotio & + & + \\
\hline 38. & Osteoglossiformes & Notopteridae & Chital & Chitala chitala & + & + \\
\hline 39. & Osteoglossiformes & Notopteridae & Foli & Notopterus notopterus & ++ & + \\
\hline 40. & Perciformes & Anabantidae & Kawai'in & Anabas testudineus & ++ & ++ \\
\hline 41. & Perciformes & Anabantidae & Koi & Anabas cobojius & + & + \\
\hline 42. & Perciformes & Badidae & Napte koi & Badis badis & ++ & + \\
\hline 43. & Perciformes & Ambassidae & Lomba chanda & Chanda nama & +++ & +++ \\
\hline 44. & Perciformes & Ambassidae & Gol chanda & Chanda beculis & +++ & +++ \\
\hline 45. & Perciformes & Ambassidae & Ranga chanda & Chanda ranga & +++ & +++ \\
\hline 46. & Perciformes & Channidae & Gozar & Channa marulius & + & + \\
\hline 47. & Perciformes & Channidae & Gachua & Channa orientalis & ++ & ++ \\
\hline 48. & Perciformes & Channidae & Taki & Channa punctata & ++ & ++ \\
\hline 49. & Perciformes & Channidae & Shol & Channa striata & ++ & ++ \\
\hline 50. & Perciformes & Osphronemidae & Khailsha & Colisa fasciata & +++ & ++ \\
\hline 51. & Perciformes & Osphronemidae & Lal kholisha & Colisa lalia & ++ & ++ \\
\hline 52. & Perciformes & Gobiidae & Bele & Glossogobius giuris & ++ & ++ \\
\hline 53. & Siluriformes & Schilbeidae & Kajuli & Ailia coila & + & + \\
\hline 54. & Siluriformes & Sisoridae & Baghair & Bagarius bagarius & + & + \\
\hline 55. & Siluriformes & Bagridae & Tengra & Batasio batasio & + & + \\
\hline 56. & Siluriformes & Clariidae & Magor & Clarius batrachus & ++ & + \\
\hline 57. & Siluriformes & Schilbeidae & Muribacha & Clupisoma garua & ++ & + \\
\hline 58. & Siluriformes & Schilbeidae & River catfish & Eutropiichthys vacha & + & + \\
\hline 59. & Siluriformes & Sisoridae & Catfish & Gagata gagata & + & + \\
\hline 60. & Siluriformes & Heteropneustidae & Shingi & Heteropneustes fossilis & ++ & + \\
\hline
\end{tabular}


Asian J. Med. Biol. Res. 2015, 1 (2)

\begin{tabular}{|l|l|l|l|l|l|l|}
\hline Sl. No. & Order & Family & Local name & Scientific Name & Sanctuary & $\begin{array}{l}\text { Non- } \\
\text { sanctuary }\end{array}$ \\
\hline 61. & Siluriformes & Bagridae & Tengra & Mystus bleekeri & ++ & + \\
\hline 62. & Siluriformes & Bagridae & $\begin{array}{l}\text { Stripped dwarf } \\
\text { catfish }\end{array}$ & Mystus tengara & ++ & ++ \\
\hline 63. & Siluriformes & Bagridae & Tengra & Mystus vittatus & ++ & ++ \\
\hline 64. & Siluriformes & Siluridae & Kani pabda & Ompok bimaculatus & + & + \\
\hline 65. & Siluriformes & Siluridae & Madhu pabda & Ompok pabda & + & + \\
\hline 66. & Siluriformes & Bagridae & Air & Sperata aor & + & + \\
\hline 67. & Siluriformes & Bagridae & Guizza & Sperata seenghala & + & + \\
\hline 68. & Siluriformes & Siluridae & Boal & Wallago attu & + & + \\
\hline 69 & Synbranchiformes & Mastacembelidae & Tara baim & Macrognathus aculeatus & ++ & ++ \\
\hline 70. & Synbranchiformes & Mastacembelidae & Pankal baim & Macrognathus pancalus & ++ & + \\
\hline 72. & Synbranchiformes & Mastacembelidae & Baim & Mastacembelus armatus & + & + \\
\hline 73. & Synbranchiformes & Synbranchidae & Kuchia & Monopterus cuchia & + & + \\
\hline 74. & Synbranchiformes & Synbranchidae & Bamosh & Ophisternon bengalense & + & + \\
\hline 75. & Tetraodontiformes & Tetraodontidae & Tepa & Tetraodon cutcutia & ++ & + \\
\hline
\end{tabular}

+++ Very common; ++ common; + rare; and - absent

Table 3. Catch per unit effort of major fishing gears of Balla beel.

\begin{tabular}{|l|l|l|l|l|}
\hline \multicolumn{2}{|l|}{ Name of fishing device } & $\begin{array}{l}\text { Time of unit effort } \\
(\mathbf{m i n})\end{array}$ & Effort/day & Average CPUE (kg/day) \\
\hline \multirow{4}{*}{} & Teta/koach & $120-180$ & $4-5$ & 5.93 \\
\cline { 2 - 5 } & Veshal jal & $30-45$ & $30-40$ & 11.33 \\
\cline { 2 - 5 } & Thela jal & $10-15$ & $40-50$ & 2.84 \\
\cline { 2 - 5 } & Ber jal & $120-150$ & $2-3$ & 22.37 \\
\cline { 2 - 5 } & Current jal & $360-720$ & $1-2$ & 7.40 \\
\cline { 2 - 5 } & Long line & $360-720$ & $1-2$ & 7.38 \\
\cline { 2 - 5 } & Koi jal & $120-150$ & $2-3$ & 6.12 \\
\cline { 2 - 5 } & Sutar jal & $120-180$ & $1-2$ & 10.32 \\
\cline { 2 - 5 } & Dharma jal/lift net & $20-30$ & $40-50$ & 9.60 \\
\hline \multirow{5}{*}{ Kua/katha } & Katha & 337.31 & $1-2$ & 398.32 \\
\hline & & & & \\
\hline
\end{tabular}

Table 4. Plankton biomass inside and outside the sanctuary of Balla beel .

\begin{tabular}{|l|l|l|l|l|l|}
\hline \multicolumn{2}{|l|}{ Phyto-plankton (nos/L) } & $\begin{array}{l}\text { Zoo-plankton } \\
(\text { nos/L) }\end{array}$ & Total plankton & Phytoplankton (\%) & $\begin{array}{l}\text { Zooplankton } \\
(\%)\end{array}$ \\
\hline Inside & $24,510 \pm 7,922$ & $607 \pm 109$ & $25,117 \pm 8,114$ & $97.60 \pm 0.22$ & $2.40 \pm 0.24$ \\
\hline Outside & $27,683 \pm 7,273$ & $869 \pm 173$ & $28,552 \pm 7,486$ & $96.90 \pm 0.17$ & $3.10 \pm 0.18$ \\
\hline
\end{tabular}


Table 5. List of different group of plankton found in Balla beel.

\begin{tabular}{|c|c|c|c|}
\hline \multirow{2}{*}{$\begin{array}{l}\text { Plankt } \\
\text { on }\end{array}$} & \multirow[t]{2}{*}{ Family } & \multicolumn{2}{|c|}{ Genera } \\
\hline & & Sanctuary area & Non-sanctuary area \\
\hline \multirow{6}{*}{ 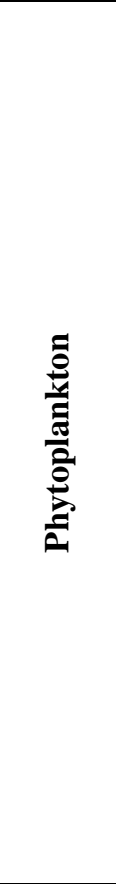 } & Chlorophyceae & $\begin{array}{l}\text { Ankistrodesmus, Chlamydomonas, } \\
\text { Chlorella, Closterium, Crucigenia, } \\
\text { Mougeotia, Pediastrum, Scenedesmus, } \\
\text { Selenestrum, Staurastrum, Spirogyra, } \\
\text { Spirotaenia, Volvox }\end{array}$ & $\begin{array}{l}\text { Ankistrodesmus, Chlamydomonas, } \\
\text { Chlorella, Closterium, Cosmarium, } \\
\text { Crucigenia, Mougeotia, } \\
\text { Palmellococcus, Pediastrum, } \\
\text { Scenedesmus, Selenestrum, } \\
\text { Spirogyra, Staurastrum, Volvox, } \\
\text { Zygnema }\end{array}$ \\
\hline & Myxophyceae & $\begin{array}{l}\text { Anabaena, Anacystis, Aphanocapsa, } \\
\text { Coelospharium, Chlorococcus, } \\
\text { Gomphosphaeria, Merismopedia, } \\
\text { Microcystis, Nostoc, Oscillatoria, } \\
\text { Spirulina, Tetrapedia }\end{array}$ & $\begin{array}{l}\text { Anabaena, Anacystis, } \\
\text { Chlorococcus, Merismopedia, } \\
\text { Microcystis, Oscillatoria, } \\
\text { Tetrapedia }\end{array}$ \\
\hline & Bacillariophyceae & $\begin{array}{l}\text { Amphora, Asterionella, , Cyclotella, } \\
\text { Coscinodiscus, Diatoma, Gyrosigma, } \\
\text { Melosira, Navicula, Nitzschia, Synedra, } \\
\text { Stephanodiscus }\end{array}$ & $\begin{array}{l}\text { Amphora, Cyclotella, Diatoma, } \\
\text { Melosira, Navicula, Nitzschia, } \\
\text { Synedra, Tabellaria }\end{array}$ \\
\hline & Euglenophyceae & Euglena, Phacus & Euglena, Phacus \\
\hline & Xanthophyceae & Chloranllanthus, Tribonema & Tribonema \\
\hline & Dinophyceae & $\begin{array}{l}\text { Mesotaenium, Netrium, Protococcus, } \\
\text { Tetraspora, Ulothrix }\end{array}$ & Netrium, Tetraspora, Ulothrix \\
\hline \multirow{10}{*}{ 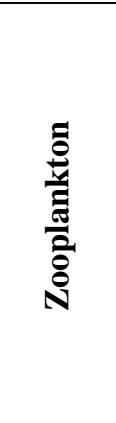 } & Brachionidae & Brachionus, Keratella & Brachionus, Keratella \\
\hline & Bosminidae & Bosmina & Bosmina \\
\hline & Cyclopidae & Cyclops & Cyclops \\
\hline & Diaptomidae & Diaptomus & Diaptomus \\
\hline & Daphnidae & Daphnia, Nauplius & Daphnia, Nauplius \\
\hline & Polycystidae & - & Polycystis \\
\hline & Sididae & Sida & Sida \\
\hline & Synchaetidae & Cypris, Polyarthra & Polyarthra \\
\hline & Testudinellidae & Filinia & Filinia \\
\hline & Trichocercidae & Trichocerca & Trichocerca \\
\hline
\end{tabular}

Table 6. Aquatic weeds of the Balla beel.

\begin{tabular}{|c|c|c|c|c|c|}
\hline Sl. No. & Local Name & Scientific Name & Type & Sanctuary & $\begin{array}{l}\text { Non- } \\
\text { sanctuary }\end{array}$ \\
\hline 1. & Kachuripana & Eichhornia crassipes & Floating & +++ & ++ \\
\hline 2. & Topapana & Pistia stratiotes & Floating & + & ++ \\
\hline 3. & Edurkanipana & Wolffia arrhiza & Floating & ++ & + \\
\hline 4. & Khudipana & Lemna minor & Floating & + & + \\
\hline 5. & Kutipana & Azolla pinnata & Floating & + & ++ \\
\hline 6. & Dal & Hydroryza aristota & Emergent & + & +++ \\
\hline 7. & Amrul shak & Oxalis corniculata & Emergent & - & - \\
\hline 8. & Shusnishak & Marsilea quadrifolia & Emergent & - & + \\
\hline 9. & Bishkatali & Polygonum hydropiper & Emergent & - & + \\
\hline 10. & Kachu & Colocasia esculenta & Emergent & - & + \\
\hline 11. & Najas & Najas najas & Submerged & ++ & ++ \\
\hline 12. & Arail & Leersia hexandra & Spreading & + & +++ \\
\hline 13. & Helencha & Enhydra flucktuans & Spreading & + & + \\
\hline 14. & Kalmilata & Ipomoea aquatica & Spreading & - & + \\
\hline 15. & Kanaibashi & Commelina bengalensis & Spreading & - & + \\
\hline 16. & Malancha & Ehhydra sp & Spreading & + & ++ \\
\hline 17. & Arrowhead & Sagitaria sagitifollia & Emergent & + & ++ \\
\hline 18. & Keshordam & Jussiaea ripens & Spreading & + & ++ \\
\hline
\end{tabular}




\begin{tabular}{|c|c|c|c|c|c|}
\hline Sl. No. & Local Name & Scientific Name & Type & Sanctuary & $\begin{array}{c}\text { Non- } \\
\text { sanctuary }\end{array}$ \\
\hline 19. & Lalshapla & Nymphaea rubna & $\begin{array}{l}\text { Rotted plants with } \\
\text { floating leaves }\end{array}$ & + & ++ \\
\hline 20. & Shapla & Nymphaea nouchali & $\begin{array}{l}\text { Rotted plants with } \\
\text { floating leaves }\end{array}$ & + & ++ \\
\hline 21. & Padma & Nelumbo nucifera & $\begin{array}{l}\text { Rotted plants with } \\
\text { floating leaves }\end{array}$ & + & ++ \\
\hline 22. & Shakata chechra & Scirpus actus & Emergent & + & ++ \\
\hline 23. & Panikola & Ludwigia adscendens & Submerged & ++ & ++ \\
\hline 24. & Dhol Kalmi & Ipomoea fistulosa & Spreading & - & + \\
\hline
\end{tabular}

+++ Very common; ++ common; + rare; and - absent

\subsection{Aquatic weeds}

About 24 aquatic weeds were found in the Balla beel, among them both emergent and spreading were $29 \%$ followed by floating 21\%; $13 \%$ were rooted plants with floating leaves and $8 \%$ were submerged (Table 6), which are comparable with the finding of Sugunan and Bhattacharjea (2000) in case of floodplain of Brahmaputra basin. The weeds usually grow along the beel margins and absent in the deeper regions. In the sanctuary area of the beel, Eichhornia crassipes was found as very common (+++) species where Wolffia arrhiza, Najas najas, Ludwigia adscendens were found in common (++) and the rest were in rare condition. The weeds were used as human consumption, cattle food and main food of buffalo. These weed also used as feed, shelter and breeding place for the resident species. FAP-16 (1992) reported less abundant macrophytes from Surma-Kushiyara floodplain project. Rahman (1992) could not find any find floating aquatic vegetation from the spawning location of Halda, the Jamuna, and the Brahmaputra river and no significant relationship existed between the aquatic and the spawning of major carps. A unique feature of floodplain wetlands was the rich growth of marginal and submerged macrophytes due to allochthonous and autochthonous nutrient loading, which often tends to replace plankton community and hastens the pace of eutrophication.

\section{Conclusions}

In floodplain wetland, water quality influenced largely by inflow of water from the connecting river, the run-off water mainly due to silt and organic debris carried the turbidity in beel water. The basin and aquatic soil can influence the value of $\mathrm{pH}$. The variation in the concentration of $\mathrm{DO}$ and $\mathrm{CO}_{2}$ were mainly due to the rate of photosynthetic activity by aquatic vegetation and variation in the organic matter contents in the basin soil. The DO levels of beel water were not high but within the acceptable limit for the growth of fishes. Balla beel was found to be conducive to enhanced fisheries, capture fisheries and biological production as well. In order to promote biodiversity, the deep area of the beel must be declared as sanctuaries to protect the aquatic lives in all season. Strict enforcement of fish Act-1950, forbidding unplanned digging and sedimentation; avoid unplanned construction of flood control, embankments, drainage system and sluice gates, conversion of inundated land to cropland (reducing water area); and controlling use of pesticides and agrochemicals in the beel and flood plain area would be some recommendations to protect the beel biodiversity. The above issue will be lead to ensure the food security of the people of Bangladesh.

\section{Conflict of interest}

None to declare.

\section{References}

Ahmad N, 1962. Fishing gear of East Pakistan. Government of East Pakistan. Directorate of Fisheries. Dhaka, $37 \mathrm{p}$.

Ahmed, K. K., M. K. I. Haque, G. C. Halder and S. B. Saha (1997). Ecological studies on the plank tonic organisms of Kaptai Lake. Bangladesh J. Agrl., 22: 63-67.

Ali MY, 1991. Towards sustainable development: fisheries resources of Bangladesh Internatioal Union for Conservation of nature and Natural Resources. The World Conservation Union. National Conservation Strategy of Bangladesh and Bangladesh Agricultural Research Council. 96 p. 
American Public health Association (APHA), 1995. Standard Methods for the Examination of Water and Waste Water. American Public Health Association, 1015 Eighteenth Street, N.W. Washington, D.C. 874p.

Bernacsek GMS, S Nandi and NC Paul, 1992. Draft thematic study: fisheries in the North East Region of Bangladesh. North West Hydraulic Consultants in association with Engineering and Planning Consultants Ltd., and Bangladesh Engineering and Technological Services, Dhaka, Bangladesh, April1992. 122p.

Boyd CE, 1982. Water Quality Management for Pond Fish Culture. Elsevier, the Netherlands. 318 pp.

Chakraborty BK, 2009. Aquatic biodiversity of Someswari and Nethai River; Gharia and Nidaya Beel of Northern Bangladesh. In Aquaculture Research Progress, Nova Science Publishers, New York, USA, pp. 3231-268.

Chakraborty BK, 2010. Status and Position of Aquatic Biodiversity of Four Beels and its Floodplain Level of Northern Bangladesh with a Good Practice of Beel Nurseries and Community Based Co-Management Policy. In Advances in Environmental Research (Vol. 8). Nova Science Publishers, New York, USA, pp. 121-164.

Chakraborty BK, MI Miah, MJA Mirza and MAB Habib, 2003. Rearing and nursing of local sarpunti, Puntius sarana (Hamilton) at different stocking densities. Pakistan J. Biolo. Sci., 9: 797-800.

Chakraborty TR, A Adrika, and MB Hossain, 2005. Fish and Wildlife of the Chanda beel Area. IUCNBangladesh: Dhaka.

Clesceri LS, AE Greenberg and RR Trussell, 1989. Standard Methods of the Examination of Water and Wastewater (17th ed.). American Public Health Association, American Water Works Association and Water Pollution Control Federation, 1015 Washington D. C., USA 20036, pp.10-203.

FAP-16 (1992). Environmental impact assessment case study Surma - Kushiyara Pproject. Bangladesh Flood Action plan, Ministry of Irrigation, Water Development and Flood Control, Flood Plan Coordination Organization (FPCO). pp.11-14

Haque MZ, MA Rahman and MM Hossain, 1993. Studies on the effect of stocking densities on the growth and survival of mrigal (Cirrhinus mrigala) fry in rearing ponds. Bangladesh J. Zool., 2: 51-58.

Haroon, A. K. Y., G. C. Halder, S. L. Rahman, M. A., Razzaque, M. Alam and S. M. Nurul Amin (2002). Sylhet-Mymensingh Basin Fish Stock Assessment. Final Report. Bangladesh Fisheries Research Institute, Reverine Station, Chandpur, Bangladesh 81 p.

IUCN, 1998. List of threatened animals of Bangladesh. Paper presented in the Special Workshop on Bangladesh Red Book of Threatened Animals, 22 February 1998, Dhaka, Bangladesh. 13 pp.

IUCN, 2000. Red book of threatened Fishes of Bangladesh. IUCN, the World Conservation Union xii+116 pp.

Keshavanath, P., B. Gangadhar, T. J. Ramesh, J. M. Van Rooij, M. C. M. Beveridge, D. J. Baird, M. C. J. Verdegem and A. A. Van Dam (2002). The effects of periphyton and supplemental feeding on the production of the indigenous carps Tor khudree and Labeo fimbriatus. Aquaculture, 213: 207-218.

Khan HR, 1993. Water development activities and their impacts on wetlands. In Freshwater wetlands in Bangladesh: Issues and Approaches for management. IUCN, Gland Switzerland. pp 23-32.

Kohinoor AHM, MA Hossain and MG Hussain, 1994. Semi-intensive culture and production cost of pabda (Ompok pabda) with rajputi (Puntius gonionotus) and mirror carp (Cyprinus carpio var.specularis) in mini ponds. Bangladesh J. Zool., 25: 129-133.

Mahbub UH, 2012. Impact of Baikka Beel Sanctuary on Protection and Restoration of Fish Biodiversity and enhancement of local livelihood. Connecting Communities and Conservation: Co-management Initiatives Implemented by IPAC in Wetlands and Forests of Bangladesh. 177-191.

Mazid MA, 2002. Development of Fisheries in Bangladesh. In Plans and Strategic for Income Generation and Poverty Alleviation. Fisheries Research Institute, Mymensingh, Bangladesh. pp. 78-79.

Needham JG and PR Needham, 1962. A Study of Freshwater Biology. Fifth ed. Holden- day, Inc. Sanfrancisco.2: 37-41.

Nishat A, 1993. Freshwater wetlands in Bangladesh: status and issues. In Freshwater wetlands in Bangladesh: Issues and Approaches for management. IUCN, Gland Switzerland, pp. 9-22.

Presscott GW, 1962. Algae of Western Great lakes Area. Wm. C. Brown Co. Duque, IOWA. 946p.

Rahman MR and MA Rahman, 2003. Studies on the growth, survival and production of calbasu (Labeo calbasu, Ham.) at different stocking densities in primary nursing. Bull. Fac. Sci., Unv. Ryuyus, Jpn.76: 245255.

Rahman MS, 1992. Water Quality Management in Aquaculture. BRAC Prokashona, 66, Mohakhali, Dhaka, 1212, Bangladesh. 84p. 
Sarker SU, 1993. Faunal diversity and their conservation in freshwater wetlands. In Freshwater wetlands in Bangladesh issues and approaches for management. IUCN, The world Conservation Union, pp.105-122.

Suganan, V.V. and B.K. Bhattacharjya. 2000. Ecology and Fisheries of Beels In Assam. Bull. No. 104, CIFRI, Barrackpore-743101, West Bengal. 66p

Tsai C and MY Ali, 1997. Open water Fisheries of Bangladesh. The University Press Limited: Dhaka. Welch PS, 1948. Limnological Metohds. McGraw-Hill Book Company, Inc., Newyork.381p. 